\title{
Childhood overweight and obesity: evidence, prevention and response
}

\author{
Jo Mitchella,b,d and Louise Baurb,c \\ a Centre for Population Health, NSW Ministry of Health, Sydney, Australia \\ b Guest Editor, Public Health Research \& Practice, Issue 1, 2019 \\ c Discipline of Child and Adolescent Health, Sydney Medical School, University of Sydney, NSW, Australia \\ d Corresponding author: Jo.Mitchell@health.nsw.gov.au
}

\section{Article history}

Publication date: March 2019

Citation: Mitchell J, Baur L. Childhood overweight and obesity: evidence, prevention and response. Public Health Res Pract. 2019;29(1):e2911900. https://doi.org/10.17061/phrp2911900
This issue of Public Health Research \& Practice explores childhood overweight and obesity. It is published at a time of renewed national interest in the issue; in February, the Australian Government held the National Obesity Summit to inform the development of the first national strategy on obesity prevention and control in almost 10 years.

We know that child overweight and obesity is a complex issue. The Foresight obesity system atlas, developed in 2007, shows the interplay of factors that influence overweight and obesity. The atlas is consistently used by policy makers and advocates to visually demonstrate the complexity of the challenge and the need for a comprehensive response. ${ }^{1}$

We live in an obesogenic environment. Societal and technological changes over the past 30 years have created an environment where it is easy to eat more than we need and not do enough exercise. Our lives are more sedentary and we have 'designed out' opportunities to be physically active. We eat out of home more often and rely more on processed energy-dense, nutrient-poor foods and pre-prepared meals. Food marketing is sophisticated and ubiquitous. Portion sizes have increased, and even changes in the size of cutlery and tableware encourage overconsumption. ${ }^{2}$

The ‘energy gap' for children is small. Just 200-300 kilojoules in excess of daily energy requirements is all that is needed for unhealthy weight gain ${ }^{3}$ - this is the equivalent to just one or two sweet biscuits, and would require 20 minutes of walking to offset. At a time when Australian children consume more than a third of their kilojoules from junk food and drink ${ }^{4}$, and with $43 \%$ of children and $37 \%$ of adolescents being driven to school ${ }^{5}$, small changes have the potential to make a big difference.

There is consistent agreement about what policy actions are needed to address the issue. A myriad of international plans and statements provide consistent recommendations, as noted by Bauman et al. ${ }^{6}$ in this issue. We also know that there are social disparities in the prevalence of child overweight and obesity ${ }^{5}$ and recognise the need to push back on stigmatising language and victim blaming. ${ }^{7}$

There are several national initiatives under way. The Australia and New Zealand Ministerial Forum on Food Regulation is progressing several food-labelling projects, including the Health Star Rating, which is detailed ${ }^{8}$ and critically discussed ${ }^{9}$ in this issue. The Council of Australian Governments Health Council, through the Obesity Working Group, is working on initiatives to limit the promotion and availability of unhealthy food and drinks, including 
in schools, public healthcare facilities, and sport and recreation settings. It has also developed a voluntary interim guide to define unhealthy food and drinks in order to reduce the exposure of children to unhealthy food and drink marketing in settings under government control. Further, the Australian Government Department of Health is also leading the Healthy Food Partnership which is focused on food reformulation and portion size. ${ }^{10}$

However, the Australian response is fragmented, narrow and underpowered. The 2018 Senate Select Committee into the Obesity Epidemic in Australia made a number of broad-ranging recommendations. However, five out of seven committee members were signatories to dissenting reports, illustrating a reluctance to act on fiscal strategies and restrictions on advertising. ${ }^{11}$ Although there are some successful programs, these are not always delivered at a level that will have a population impact; see discussions on the issue of scalability by Innes-Hughes et al. ${ }^{12}$ and Love et al. ${ }^{13}$ in this issue. There is a strong narrative about parental responsibility that ignores environmental influences, and there is an intense 'nanny state' commentary that counters the potential for structural change. There is tension about the role of the food industry, and whether self-regulation is adequate; the recent Australian Beverages Council sugar pledge and the public health response is a case in point. ${ }^{14}$

We, as academics, clinicians, policy makers and practitioners working to address overweight and obesity in Australia, do not have a united voice; this diminishes the clarity of our narrative, weakens our position to argue for policy change, and creates uncertainty for the public and political decision makers. The recently established Obesity Collective is attempting to change this and to create a platform to better collaborate and support a range of players in society to contribute to our collective aims. ${ }^{15}$

If we are to reverse childhood overweight and obesity, we need to do more. We need a societal response that creates a movement for change. We need to put into action what we already know and deliver successful interventions at scale, over time. We need to find new, systemic solutions. And we need to be in this for the long haul.

We hope readers enjoy the themed papers and all the articles in this issue. Public Health Research \& Practice aims to deliver engaging, high-quality, peer-reviewed articles from Australian and international thought leaders, policy makers, practitioners and researchers that will inspire you, provoke debate and be useful in your work.

\section{Peer review and provenance}

Internally peer reviewed, commissioned.

\section{Competing interests}

None declared.

\section{Author contributions}

JM was responsible for drafting the paper, with input from LB. LB was responsible for reviewing and editing the paper. Both authors reviewed and approved the final version.

\section{References}

1. Vandenbroeck P, Goossens J, Clemens M. Foresight. Tackling obesities: future choices - obesity system atlas. London: Government Office for Science; 2007 [cited 2019 Feb 14]. Available from: assets.publishing.service.gov.uk/ government/uploads/system/uploads/attachment_data/ file/295153/07-1177-obesity-system-atlas.pdf

2. Hollands GJ, Shemilt I, Marteau TM, Jebb SA, Lewis HB, Wei Y, et al. Portion, package or tableware size for changing selection and consumption of food, alcohol and tobacco. Cochrane Database Syst Rev. 2015;(9):CD011045.

3. Plachta-Danielzik S, Landsberg B, Bosy-Westphal A, Johannsen M, Lange D, Müller MJ. Energy gain and energy gap in normal-weight children: longitudinal data of the KOPS. Obesity (Silver Spring). 2008;16(4):777-83.

4. Australian Bureau of Statistics. Australian health survey: nutrition first results - foods and nutrients 2011-12. Canberra: ABS; 2014 [cited 2019 Feb 19]. Available from: www.ausstats.abs.gov.au/ausstats/subscriber.nsf/0/4683 FD7315DFDFDBCA257D080014F9E0/\$File/australian\%20 health\%20survey\%20nutrition\%20first\%20results\%20 -\%20food\%20and\%20nutrients, \%202011-12.pdf

5. Hardy LL, Mihrshahi S, Drayton BA, Bauman A. NSW school physical activity and nutrition survey (SPANS) 2015: summary report. Sydney: NSW Department of Health; 2016 [cited 2019 Feb 19]. Available from: www.health.nsw.gov.au/heal/Publications/spans-2015summary-report.PDF

6. Bauman A, Rutter H, Baur L. Too little, too slowly: international perspectives on childhood obesity. Public Health Res Pract. 2019;29(1):e2911901.

7. Pont SJ, Puhl R, Cook SR, Slusser W, Section on Obesity, Obesity Society. Stigma experienced by children and adolescents with obesity. Pediatrics. 2017; 140(6):e20173034.

8. Maganja D, Buckett K, Stevens C, Flynn E. Consumer choice and the role of front-of-pack labelling: the Health Star Rating system. Public Health Res Pract. 2019;29(1):e2911909.

9. Lawrence MA, Pollard CM, Vidgen HA, Woods JL. The Health Star Rating system - is its reductionist (nutrient) approach a benefit or risk for tackling dietary risk factors? Public Health Res Pract. 2019;29(1):e2911906.

10. Australian Government Department of Health. Healthy food partnership. Canberra: Commonwealth of Australia; 2018 [cited 2019 Feb 19]. Available from: www.health. gov.au/internet/main/publishing.nsf/Content/HealthyFood-Partnership-Home 
11. Select Committee into the Obesity Epidemic in Australia. The Senate: Select Committee into the Obesity Epidemic in Australia: final report. Canberra: Commonwealth of Australia; 2018 [cited 2019 Feb 14]. Available from: www. aph.gov.au/Parliamentary_Business/Committees/Senate/ Obesity_epidemic_in_Australia/Obesity/Final_Report

12. Innes-Hughes C, Rissel C, Thomas M, Wolfenden L. Reflections on the NSW Healthy Children Initiative: a comprehensive, state-delivered childhood obesity prevention initiative. Public Health Res Pract. 2019;29(1):e2911908.

13. Love P, Laws R, Hesketh KD, Campbell KJ. Lessons on early childhood obesity prevention interventions from the Victorian Infant Program. Public Health Res Pract. 2019;29(1):e2911904.
14. Dalzell S. Soft drink industry pledges to cut sugar overall, but doctors say it's a diversion from the real issue. Sydney: ABC News; 2018 Jun 26 [cited 2019 Mar 3]. Available from: https://www.abc.net.au/news/2018-06-25/ soft-drink-industry-pledge-to-cut-sugar-criticised-byama/9906502

15. Obesity Australia. The Obesity Collective. Sydney: Obesity Australia; 2018 [cited 2019 Feb 19]. Available from: www.obesityaustralia.org/the-obesity-collective

\section{Copyright: (C) (i) (5) (2)}

(C) 2019 Mitchell and Baur. This article is licensed under the Creative Commons Attribution-NonCommercial-ShareAlike 4.0 International Licence, which allows others to redistribute, adapt and share this work non-commercially provided they attribute the work and any adapted version of it is distributed under the same Creative Commons licence terms. See: www.creativecommons.org/licenses/by-nc-sa/4.0/ 